Studia Oecumenica 17 (2017)

DOI: 10.25167/SOe/17/2017/79-94

ANDRZEJ ANDERWALd

Wydział Teologiczny UO

\title{
Postulat hermeneutycznej potrzeby relacji teologia - nauki przyrodnicze w perspektywie współczesnej protestanckiej teologii stworzenia
}

\author{
The Postulate of Hermeneutic Needs \\ of the Relationship Theology - Science in the Perspective \\ of Modern Protestant Theology of Creation
}

\begin{abstract}
The most remarkable example of the theological retreat from a discussion of the scientific description of nature can be found in the theological doctrine of creation of the German protestant theologian Karl Barth (1886-1968). In the present many the Anglo-Saxon and the German protestants theologians show a big interest in the subject of relations between science and Christian theology (especially with theology of creation). Therefor their idea of theology of creation is completely in contrast to the Barth's position rejecting the necessity of referring to the results of the natural sciences in the theology of creation. This is a relevant issue to the Christian faith. Its justification is made today in a climate of scientific thinking, in which scientific tools of recognizing of the world, as well as the scientific picture of the world, play an important role. This article will demonstrate the postulate of hermeneutic needs of the relationship theology - science based on the concept of theology of creation of two remarkable protestants theologians of twentieth century the Lutheran Wolfhart Pannenberg (1928-2014) and the representative of Reformed theology Jürgen Moltmann $(* 1926)$. Particular attention is paid to their indications that a credible doctrine of God as the Creator must take into account scientific understandings of the world.
\end{abstract}

Keywords: Wolfhart Pannenberg, Jürgen Moltmann, theology of creation, relationship theology - science.

\section{Streszczenie}

Koncepcja teologii stworzenia niemieckiego teologa protestanckiego Karla Bartha (1886-1968) dostarcza najbardziej klasycznego przykładu odwrotu w teologii protestanckiej od odnoszenia się do wiedzy przyrodniczej. Współcześnie wielu protestanckich teologów anglosaskich i niemieckich, w przeciwieństwie do tej koncepcji, odrzucającej 
konieczność odnoszenia się w teologii stworzenia do wyników nauk przyrodniczych, wykazuje duże zainteresowanie tematyką relacji doktryny chrześcijańskiej do nauk przyrodniczych. Jest to dziś ważna kwestia dla wiary chrześcijańskiej. Uzasadnienie wiary dokonuje się współcześnie w klimacie myślenia naukowego, w którym ważną rolę odgrywają naukowe narzędzia poznawcze, jak również przyrodniczy obraz świata. Artykuł prezentuje postulat hermeneutycznej potrzeby relacji teologia - nauki przyrodnicze na przykładzie koncepcji teologii stworzenia dwóch ważnych $\mathrm{w}$ teologii protestanckiej XX w. teologów: luteranina Wolfharta Pannenberga (1928-2014) i reprezentanta teologii reformowanej Jürgena Moltmanna (ur. 1926). Szczególna uwaga jest zwrócona na problem wiarygodnej doktryny Boga Stwórcy z konieczności uwzględniającej aktualny przyrodniczy obraz świata.

Słowa kluczowe: Wolfhart Pannenberg, Jürgen Moltmann, teologia stworzenia, relacja teologia - nauki przyrodnicze.

We współczesnej teologii protestanckiej, zwłaszcza w kwestii stworzenia, jest wyraźnie widoczne zainteresowanie problematyką przyrodniczą. Wśród twórczości anglosaskich teologów protestanckich, a zarazem przyrodników, takich jak: Arthur Robert Peacoke (1925-2006), Ian Greame Barbour (19232013), John Polkinghorne (ur. 1930), Philip Hefner (ur. 1932), czy Alister Edgar McGrath (ur. 1953), mających uniwersyteckie specjalizacje w różnych dyscyplinach nauk przyrodniczych, jest wyraźnie podejmowana tematyka relacji doktryny chrześcijańskiej do nauk przyrodniczych. Podobna tendencja badawcza, charakteryzująca się odmiennym sposobem realizacji w odniesieniu do nauk przyrodniczych, jest widoczna wśród niemieckich teologów protestanckich, takich jak: Sigurd Martin Daecke (ur. 1932), Wolfhart Pannenberg (1928-2014), Jürgen Moltmann (ur. 1926), Jürgen Hübner (ur. 1932), Christian Link (ur. 1938) czy Michael Welker (ur. 1947). Ta obecna współcześnie perspektywa badawcza $\mathrm{w}$ teologii protestanckiej wpisuje się w nurt badań zapoczątkowany przez Karla Heima (1874-1958) - prekursora otwarcia teologii protestanckiej na nauki przyrodnicze, w tym szczególnie $\mathrm{w}$ tworzeniu syntez między przyrodniczą teorią ewolucji a teologiczną nauką o stworzeniu. Należy jednak zauważyć, że teologii protestanckiej nie są obce również odmienne tradycje w podejściu do nauk przyrodniczych. Są one obecne szczególnie w dwóch jej nurtach: teologii dialektycznej, zainicjowanej przez Karla Bartha (1886-1968), i egzystencjalnej, reprezentowanej przez Rudolfa Bultmanna (1884-1976). Obydwa nurty charakteryzowały się tendencją do radykalnego rozdzielania kwestii teologicznych od przyrodniczych. Ich przedstawiciele, głosząc poglądy o samowystarczalności teologii i jej metod w uzasadnianiu własnych tez, kwestionowali jakąkolwiek potrzebę odnoszenia się w refleksji teologicznej do wiedzy przyrodniczej. Współcześni ich kontynuatorzy, jak Langdon Gilkey (1919-2004) czy Thomas Forsyth Torrance (1913-2007), w rozważaniach nad stworzeniem nie wprowadzają 
już ostrej neutralności między teologią a naukami przyrodniczymi, jak twórcy wymienionych nurtów ${ }^{1}$.

Celem rozważań jest prezentacja postulatu hermeneutycznej potrzeby relacji teologia - nauki przyrodnicze na przykładzie koncepcji teologii stworzenia dwóch współczesnych niemieckich teologów protestanckich: Wolfharta Pannenberga i Jürgena Moltmanna. Obaj teolodzy są dość powszechnie uważani za reprezentatywnych przedstawicieli dialogu teologii z naukami przyrodniczymi nie tylko w kręgu protestanckiej teologii niemieckiej czy anglosaskiej, ale również i w katolickiej². To, co łączy ich w uprawianiu teologii, przy całej odmienności podejmowanych przez nich szczegółowych tematów, to radykalne odejście od właściwej dla $K$. Bartha koncepcji teologii stworzenia oderwanej od przyrodniczego obrazu świata ${ }^{3}$. W toku podjętych rozważań zostaną przedstawione na tle ich koncepcji teologii stworzenia zarówno sposoby integrowania wiedzy przyrodniczej w teologii, jak i argumenty wspomnianych badaczy za podejmowaniem tego typu działań, składające się na pewnego rodzaju postulat hermeneutycznej potrzeby relacji teologia - nauki przyrodnicze.

\section{Fizyka w teologii stworzenia}

Wśród niemieckich teologów protestanckich zmarły w 2014 r. luteranin W. Pannenberg jest uważany za jednego z największych zwolenników otwarcia teologicznej refleksji na poznanie nauk przyrodniczych ${ }^{4}$. Urodzony w Szczecinie w 1928 r. Pannenberg studiował filozofię i teologię w Berlinie, Getyndze i Bazylei. Działalność naukowo-dydaktyczną w zakresie teologii systematycznej rozpoczął na uniwersytecie w Heidelbergu (1955-1958), kontynuował na uniwersytetach w Wuppertalu (1958-1961) i Moguncji (1961-1967), a następnie, aż do przejścia na emeryturę, był związany z Wydziałem Teologii Ewangelickiej Uniwersytetu w Monachium (1967-1984). Do opus magnum Pannenberga zalicza się opublikowane w latach 1988-1993 trzytomowe dzieło Systematische Theologie 5 .

${ }^{1}$ Por. H. Schwarz, 400 Jahre Streit um die Wahrheit - Theologie und Naturwissenschaft, Göttingen 2012, 94-98, 125-126.

${ }^{2}$ Por. D. Evers, Religion and Science in Germany, Zyg 50 (2015) nr 2, 517-524 http://onlinelibrary.wiley.com/doi/10.1111/zygo.12172/epdf (10.04.2017); H. ScHWARZ, 400 Jahre Streit um die Wahrheit, 180-186; R. NEININGER, Welt verstehen - an die Schöpfung glauben, Paderborn München - Wien - Zürich 2010, 19-21; H. KüNG, Der Anfang aller Dinge. Naturwissenschaft und Religion, Tübingen 2005, 52, 55, 190.

3 Por. J. Moltmann, Personal recollections of Wolfahrt Pannenberg, TTo 72 (2015) nr 1, 13.

${ }^{4}$ Por. D. Evers, Religion and Science in Germany, 519-520.

5 Por. H. Schwarz, Wolfhart Pannenberg, w: J.B. Stump, A.G. PAdGett (red.), The Blackwell Companion to Science and Christianity, Chichester 2012, 613-614; http://onlinelibrary.wiley.com/ 
Teologiczną perspektywę refleksji nad dziełem stworzenia świata luteranin z Monachium wyraża najwyraźniej we wstępie do drugiego tomu Systematische Theologie: w stwarzanie zaangażowane są wszystkie trzy Osoby Boskie, które współuczestniczą w stwarzaniu, manifestując się w historii w stwórczym powoływaniu do istnienia skończonych stworzeń ${ }^{6}$. Dlatego dość powszechnie jego koncepcja teologii stworzenia jest określana jako trynitarna ${ }^{7}$. Dla Boga jedyną racją stworzenia świata jest chęć udzielenia stworzeniom istnienia. Stwórca daje stworzeniom udział we własnym istnieniu. Pierwszorzędnym przedmiotem miłości Ojca jest Syn. Miłość Ojca kieruje się do stworzeń przez Syna. Stworzenia zaś zostają włączone w odwieczne zwrócenie się Ojca do Syna. W Synu ma swój początek samodzielność stworzeń wobec Stwórcy ${ }^{8}$. Pojęcia stworzenia Pannenberg nie ogranicza jednak tylko do początku świata, lecz odnosi je również do stwórczego działania Boga w historii świata. Za uwzględnieniem obydwu tych aspektów stworzenia przemawiają biblijne świadectwa9 ${ }^{9}$. Już samo ujęcie aktu stworzenia jako dzieła Trójjedynego Boga daje możliwość odnoszenia wypowiedzi o stworzeniu nie tylko do początku świata, lecz w ogóle do utrzymania stworzenia $\mathrm{w}$ istnieniu ${ }^{10}$. Można zatem mówić o Bożym współdziałaniu, którego jednak nie należy rozumieć jako samodzielności Boga, znoszącej samodzielność stworzeń. Działanie Boga, mające na celu zachowanie istnienia świata, określane jako creatio coninua, nie znajduje się naprzeciw samoutrzymania skończonych bytów, ale w pełni umożliwia realizowanie się samodzielności stworzeń ${ }^{11}$. Dla Pannenberga zatem utrzymanie świata przez Boga, Jego współdziałanie i kierowanie obejmują trwające nieprzerwanie stwórcze działanie Boga. Tego rodzaju stricte teologiczne zakorzenienie nauki o stworzeniu nie oznacza wcale dla tego teologa jej zamknięcia na nauki przyrodnicze, czy też próby poszukiwania możliwości skorelowania treści przyrodniczych z treściami chrześcijańskiej protologii.

Teologiczne rozważania na temat działania Boga w świecie przyrody skłaniają luterańskiego teologa, czemu daje wyraz w wielu swoich publikacjach ${ }^{12}$,

doi/10.1002/9781118241455.ch53/summary (12.03.2017); T. Peters, In Memoriam: Wolfhart Pannenberg (1928-2014), „Dialog” 53 (2014) nr 4, 365-383.

${ }^{6}$ W. Pannenberg, Systematische Theologie, t. II, Göttingen 1991, 15.

7 Por. T. Peters, In Memoriam: Wolfhart Pannenberg (1928-2014), 367; J. Moltmann, Personal recollections of Wolfahrt Pannenberg, 12.

8 W. PAnnenberg, Systematische Theologie, t. II, 36.

9 Tamże, 26.

${ }_{10}$ Tamże, 49.

11 Tamże, 65.

${ }_{12}$ Por. W. Pannenberg, Kontingenz und Naturgesetz, w: A.M. MüLler, tenże (red.), Erwägungen zu einer Theologie der Natur, Gütersloh 1970, 34-57; TENŻE, Gott und die Natur. Zur Geschichte der Auseinandersetzung zwischen Theologie und Naturwissenschaft, ThPh 58 (1983), 481-500; TENŻE, Schöpfungstheologie und moderne Naturwissenschaft, w: H. DEUSER (red.), Gottes Zukunft - Zukunft 
do poszukiwań ewentualnych możliwości ich uzgodnienia z obowiązującymi w przyrodzie prawami, a ostatecznie do określenia relacji między teologią i naukami przyrodniczymi. Możliwość taką widzi on we właściwej interpretacji praw przyrody, które opisują powtarzalne zjawiska i zasadniczo opierają się na powtarzalnych eksperymentach. Prawa te opisują konkretny porządek zdarzenia $\mathrm{w}$ aspekcie jednakowych, powracających etapów jego przebiegu. W powtarzalności i jednakowości nie wyczerpuje się całe bogactwo danego zdarzenia, ponieważ jego wyjątkowość i kontyngencja nie jest przedmiotem badań nauk przyrodniczych ${ }^{13}$. Pannenberg postuluje zatem, w celu pełnego ukazania prawdy o stworzeniu, aby wszelkie jednakowe zdarzenia naznaczone przygodnością i historycznością włączać w stworzenie, gdyż prawidłowości przyrody opisywane przez prawa przyrody nie sprzeciwiają się prawdzie o stworzeniu. Stałość praw przyrody stanowi dla Pannenberga warunek samodzielności stworzeń. Bez założenia ważności praw przyrody jako warunku samodzielności stworzeń nie mogą one zachować swojej samodzielności w stosunku do Boga i zostać włączone w relację Ojca do Syna. Prawa przyrody mają zatem do spełnienia istotną, służebną funkcję w trynitarnej historii stworzenia ${ }^{14}$.

Odwołanie się do hermeneutycznej relacji teologia - nauki przyrodnicze jest widoczne w proponowanym przez Pannenberga ujęciu teologii stworzenia. Najwyraźniej staje się to dostrzegalne w odwołaniu się do fizykalnego pojęcia pola. Konkretnie chodzi tu o jego odwołanie się do pojęcia pola wypracowanego na terenie fizyki przez Michaela Faradaya (1791-1867). Dla teologa z Monachium jest możliwe ustalenie korelacji pomiędzy biblijno-teologicznym pojęciem „duch” (pneuma) a przyrodniczym pojęciem pola, czyli złączenie fizykalnej teorii pola z chrześcijańską nauką o dynamicznej działalności boskiego Ducha $\mathrm{w}$ stworzeniu ${ }^{15}$. Tego typu połączenie nie ma na celu zakwestionowania istotnych różnic pomiędzy teologicznym a przyrodniczym sposobem opisu rzeczywistości ani nie jest próbą narzucenia bezpośredniej teologicznej interpretacji fizycznej teorii pola ${ }^{16}$. Nauki przyrodnicze, podobnie jak teologia, w swoich opisach zawsze zbliżają się do tej samej rzeczywistości. Podobną funkcję ma spełnić zastosowanie pojęcia pola w refleksji nad stworzeniem. Zawsze chodzi o tę samą rzeczywistość, do której poznania zbliżają się w sobie właściwy sposób nauki przyrodnicze i która jest przedmiotem teologicznych wypowiedzi o stworzeniu. Więcej, Pannenberg uważa, że tworząc teologiczne pojęcia, można niejako we-

der Welt, München 1986, 137-148; TENżE, Theologie der Schöpfung und Naturwissenschaft, w: J. Dorschner (red.), Mensch und Universum, Regensburg 1995, 147-152.

13 W. Pannenberg, Systematische Theologie, t. II, 83.

${ }^{14}$ Tamże, 92.

15 Por. W. Pannenberg, God as spirit - and natural science, Zyg 36 (2001) nr 4, 783-794.

${ }^{16}$ TeNŻE, Systematische Theologie, t. II, 102. 
wnątrz prowadzonej z ich wykorzystaniem refleksji stosować odmienne formy opisu (np. opisy fizyczne). Posłużenie się tego rodzaju strategią pozwala zachować koherencję teologicznych i przyrodniczych wypowiedzi o świecie ${ }^{17}$. W tym sensie teologia może, zgodnie z sugestią Pannenberga, skorzystać z przyrodniczego pojęcia pola. Takie ujęcie, odwołujące się do dynamicznego pola, stwarza możliwość lepszego wyrażenia działania boskiego Ducha w jedności Trójcy Świętej. Samo pojęcie pola jest czymś więcej niż tylko metaforą, gdyż występuje tu jako sposób przybliżający działanie Bożego Ducha w świecie. Oczywiście działanie Ducha Świętego w świecie nie jest u Pannenberga tożsame z fizycznym pojęciem pola, którego funkcjonowanie rozumie on jako wyjątkową „manifestację" dla Jego działania. Użycie w teologii stworzenia pojęcia pola jest czymś więcej niż tylko pewnym obrazem, metaforą, prowadzi bowiem do lepszego zrozumienia dynamiki Bożego Ducha ${ }^{18}$. Równocześnie nie chodzi tu o zacieranie różnic między treścią przypisywana pojęciu dynamiki Bożego Ducha a treścią pojęcia pola w fizyce.

Jeszcze innym zagadnieniem, które wskazuje na zastosowanie postulatu hermetycznej relacji teologia - nauki przyrodnicze, jest kwestia rozumienia początku wszechświata. Pannenberg widzi konieczność otwarcia teologicznej nauki o stworzeniu na kosmologię i jej teorie na temat początku wszechświata. Spór o początek wszechświata zainicjowany w starożytności jest obecny i dziś w alternatywnych modelach współczesnej kosmologii. To, czy można mówić o początku czasowym wszechświata, jest związane z faktem, czy świat jako całość jest ujmowany jako skończony albo nieskończony. Pannenberg skłania się ku akceptacji modelu standardowego, wiążącego początek czasowy wszechświata z prawybuchem ${ }^{19}$. Nie da się opisać fizyki samego początku wszechświata, a tym bardziej tego, co było przed jego początkiem. Samo dokładne wyznaczenie owego początku nie jest jednak istotne dla teologii stworzenia. O wiele bardziej znaczące stają się kosmologiczne rozważania na temat skończoności świata. W ramach przyrodniczej dyskusji na temat śmierci cieplnej wszechświata sugeruje się, iż tego rodzaju zdarzenie znajduje się poza historią ludzkości, ponieważ warunki dla życia organicznego wygasną dużo wcześniej. Przeciwnie do przyrodniczego rozumienia końca świata jego biblijne oczekiwanie końca jest ściśle związane z historią człowieka. Tu jest szczególnie widoczne, jak teologiczna argumentacja porusza się na innym poziomie niż argumentacja przyrodnicza, choć dostrzec można także zbieżność zasadniczego wątku głównych myśli obydwu naukowych sposobów argumentowania, przyrodniczego i teologicznego, w kwestii początku

\footnotetext{
17 W. Pannenberg, Systematische Theologie, t. II, 103.

18 Por. TenżE, Geist als Feld - nur eine Metapher?, ThPh 71 (1996), 257-260.

19 Tenże, Systematische Theologie, t. II, 177.
} 
wszechświata ${ }^{20}$. Uwzględnienie relacji teologia - nauki przyrodnicze w kwestii dotyczącej początku wszechświata daje możliwość spójnego wyjaśnienia dzieła stworzenia z uwzględnieniem płaszczyzny teologicznej i przyrodniczej. Podobnie postępuje Pannenberg, gdy analizuje wpływ odkryć w fizyce na zmiany w interpretacji praw przyrody i ich znaczenie dla teologii stworzenia ${ }^{21}$. Choć samo jego odnoszenie się do fizyki (w tym szczególnie pojęcia pola) budzi wątpliwości zarówno przyrodników, jak i teologów ${ }^{22}$, to jednak tego typu postępowanie poznawcze ma na celu ukazanie możliwości zharmonizowania przyrodniczej i teologicznej perspektywy.

Podsumowując można stwierdzić, iż obecne w teologii stworzenia teologa z Monachium wyraźne odniesienia do nauk przyrodniczych dobrze ilustrują hermeneutyczną potrzebę relacji teologia - nauki przyrodnicze. Uwzględnienie tej relacji w teologii stworzenia ukazuje, w jaki sposób, wychodząc od wydarzenia Bożego objawienia, można zaproponować wspólnie z przyrodnikami interpretację działania Boga w świecie, w tym powstania świata i człowieka. Ponadto chroni ją przed zawężaniem się jedynie do interpretacji teologicznego przesłania pierwszych dziesięciu rozdziałów Księgi Rodzaju czy też ich egzystencjalnego przesłania. Zawsze takie samoograniczenie się teologii stworzenia pozbawia ją jakiejkolwiek możliwości oddziaływania na interpretacje przyrody inspirowane jedynie jej wyjaśnieniami dostarczanymi przez nauki przyrodnicze. Odnoszenie się do wspomnianej relacji nie pozostaje również bez znaczenia dla budowania rozumnych podstaw wiary chrześcijańskiej otwartej na przyrodniczy obraz świata.

\section{Biologia w teologii stworzenia}

Jürgen Moltmann, urodzony w 1926 r. w Hamburgu, studiował filozofię i teologię w Getyndze, a zasadniczą działalność naukowo-dydaktyczną związał z uniwersytetem w Tybindze (1967-1992). Główne nurty badawcze Moltmanna, dotyczące teologii nadziei i krzyża oraz koncepcji Kościoła, zawierają się w trzech dziełach: Teologia nadziei (Theologie der Hoffnung, 1964), Bóg ukrzyżowany (Der gekreuzigte Gott, 1972) i Kościót w mocy Ducha (Kirche in der Kraft des Geistes, 1975)23. Ważnym wątkiem w jego twórczości jest również oryginal-

20 Tamże, $187 \mathrm{n}$.

${ }^{21}$ Por. TENŻE, Kontingenz und Naturgesetz, 39-41.

22 Por. A. LeBKÜCher, Theologie der Natur. Wolfhart Pannenberg Beitrag zum Dialog zwischen Theologie und Naturwissenschaft, Neukirchen-Vluyn, 2011, 203-205.

${ }^{23}$ Por. Z. Danielewicz, Teolog wierny nadziei, w: J. Majewski, J. Makowski (red.), Leksykon wielkich teologów XX/XXI wieku, Warszawa 2003, 182-191; zob. także: Jürgen Moltmann 
na koncepcja teologii stworzenia zawarta w pracy pt.: Gott in der Schöpfung ${ }^{24}$. Opracowanie to oraz późniejsza monografia pt. Wissenschaft und Weisheit ${ }^{25}$ dają postawę do określenia jego stanowiska co do potrzeby uwzględniania relacji teologia - nauki przyrodnicze w refleksji teologicznej.

Moltmann, podobnie jak Pannenberg, rozważania nad stworzeniem prowadzi w szerszej perspektywie uprawiania tzw. teologii przyrody. Jak informuje podtytuł oryginału Gott in der Schöpfung, chodzi o naukę o stworzeniu ukierunkowaną ekologicznie (Ökologische Schöpfungslehre). Realizacja tak zorientowanej teologii stworzenia domaga się odrzucenia analitycznego myślenia z właściwym mu podziałem na podmiot i przedmiot, który traktuje świat zewnętrzny wobec dominującego myślącego podmiotu w kategoriach przedmiotowych. Zamiast tego Moltmann proponuje, aby sięgnąc do nowych, integrujących różne płaszczyzny poznawcze sposobów myślenia ${ }^{26}$. Ideą przewodnią jego teologii stworzenia jest zatem integrowanie, ukierunkowanie ku tworzeniu wspólnoty między człowiekiem a przyrodą, Bogiem a światem. Tak uprawiana teologia jest inspirowana chęcią znalezienia i odnowienia pierwotnej komunii stworzenia ${ }^{27}$. Stąd w centrum rozważań Moltmanna znajduje się nie tyle, właściwe dla wielu protestanckich koncepcji stworzenia, rozróżnienie pomiędzy Bogiem a światem, ile poznanie Bożego działania i Jego obecności w świecie. Obce jest mu również, charakterystyczne dla tych koncepcji, oddzielanie antropologii biologicznej od teologicznej, czy w ogóle kwestionowanie znaczenia antropologii biologicznej ${ }^{28}$. Jedną z konsekwencji tak sformułowanego celu jest integralne podchodzenie do ewolucji biologicznej i teologii stworzenia jako nie dwóch konkurujących bądź przeciwnych sposobów ujmowania rzeczywistości, lecz komplementarnych ujęć jednej rzeczywistości. Za takim ujęciem przemawia również chęć udzielenia odpowiedzi na centralne dla książki Bóg $w$ stworzeniu pytanie o możliwość wiary w Boga Stwórcę w kontekście zniszczenia przyrody. Jest to możliwe, jeśli z konieczności zostanie podjęty dialog teologii ze znajdującymi się w stanie przemian naukami przyrodniczymi ${ }^{29}$.

Punktem wyjścia dla chrześcijańskiej nauki o stworzeniu jest właściwa interpretacja biblijnych tekstów o stworzeniu. Opisane w Biblii doświadczenie

Reading Room: https://www.tyndale.ca/seminary/mtsmodular/reading-rooms/theology/moltmann (3.03.2017).

${ }^{24}$ J. Moltmann, Gott in der Schöpfung. Ökologische Schöpfungslehre, München 1985. Wyd. pol.: Bóg w stworzeniu, Kraków 1995.

25 J. Moltmann, Wissenschaft und Weisheit. Zum Gespräch zwischen Naturwissenschaft und Theologie, Gütersloh 2002.

26 J. Moltmann, Bóg w stworzeniu, 36.

27 Tamże, 39.

28 Por. P. JASKÓŁA, Boży duch i ludzka dusza w myśli teologicznej, RTSO 29 (2009), 299-300.

29 J. Moltmann, Bóg w stworzeniu, 37-38, 61, 63-64. 
świata jako stworzenie jest rezultatem wiary w objawienie się Boga Stwórcy w historii Izraela. Dla reformowanego teologa z Tybingi świat sam z siebie nie daje się poznać jako stworzenie. Dopiero w świetle Bożego objawienia zachodzi możliwość poznania świata jako dzieła Bożego stworzenia ${ }^{30}$. Konsekwentnie zatem jeśli pojęcie stwarzania, zakresowo szersze niż pojęcie przyrody, ma odnosić się do całego Bożego stwarzania, nauka o stworzeniu musi obejmować sam początek stworzenia (creatio orginalis) - stwarzanie w historii (creatio continua) oraz stworzenie końca czasów (creatio nova). Integralne podejście do procesów stwarzania dobrze harmonizuje z samą jednością Boga. Dlatego biblijna teologia stworzenia w ujęciu Moltmanna obejmuje zarówno jego aspekt protologiczny, jak i eschatologiczny ${ }^{31}$. Stworzenie na początku wskazuje na biblijne obietnice dane przez Boga Abrahamowi, Izaakowi i Jakubowi. Te z kolei skierują uwagę na mesjańskie zapowiedzi Nowego Testamentu, które wspólnie odnoszą się do przyszłego Królestwa, które odnowi niebo i ziemię ${ }^{32}$. Poznanie świata jako stworzenia oznacza zatem dla Moltmanna zauważenie, iż szczególnie w kerygmie o zmartwychwstaniu i doświadczeniu Ducha Świętego jako mocy nowego stworzenia znajduje się istota nowotestamentalnego świadectwa o stworzeniu.

Charakterystyczne dla Moltmannowskiej koncepcji stworzenia jest, jeszcze wyraźniejsze niż u Pannenberga, zwrócenie uwagi na zaangażowanie całej Trójcy Świętej w dzieło stwarzania. Bóg Ojciec jest stworzycielem świata, Syn skonsolidował i wybawił świat pod wyzwalającym panowaniem Boga, zaś Duch Święty - jako stwórcza moc - ożywia świat i pozwala mu mieć udział w życiu Boga. Stworzenie jest zatem z Boga, przez Niego i w Nim. Tym samym zaproponowana przez Moltmanna trynitarna koncepcja stworzenia łączy w sobie Bożą transcendencje wobec świata z Bożą immanencją w świecie ${ }^{33}$. Akt stworzenia opisany w Księdze Rodzaju nie ma jakiejkolwiek analogii w świecie przyrody. Moltmann widzi wyraźnie różnicę pomiędzy stworzeniem (hebr. bara) a czynieniem (hebr. asa). Akt stworzenia opisuje Boże działanie jako konieczne, wolne od założeń. Rezultatem tak określonego stworzenia jest coś całkowicie nowego, co ani faktycznie, ani potencjalnie nie może zostać uczynione przez jakikolwiek inny byt ${ }^{34}$. Brak analogii w świecie ludzkim dla stwórczego działania Bożego sprawia, iż jest ono ostatecznie niewyobrażalne. Jedyność, pierworodność tego aktu dobrze wyraża tomistyczne pojęcie creatio ex nihilo. Sam natomiast proces

30 Tamże, 114.

${ }^{31}$ Por. A. Anderwald, Teolog pomiędzy kreacjonizmem a ewolucjonizmem. Ekologiczna nauka o stworzeniu Jürgena Moltmanna, RTSO 23 (2003), 64.

32 Tamìe.

33 J. Moltmann, Bóg w stworzeniu, 184.

${ }^{34}$ Tamże, 146. 
stwarzania opisuje on przez odwołanie do biblijnego stworzenia mocą słowa, które spełnia funkcję kontinuum pomiędzy Stwórcą a stworzeniem. Stworzenie nie jest celem samym w sobie, ale przez nie Bóg objawia swoją wolę i miłośćc ${ }^{35}$. Podstawą stworzenia jest osoba Jezusa Chrystusa, której udział w dziele stworzenia Moltmann ujmuje trojako: jako pośrednika stworzenia, siły napędowej ewolucji świata i wybawcy ewolucji ${ }^{36}$. Zasadniczo teologiczna koncepcja stworzenia teologa $\mathrm{z}$ Tybingi zawiera odniesienia do przyrodniczego obrazu świata. We wstępnym rozdziale monografii Bóg w stworzeniu Moltmann pisze: „Integrowanie i integralne myślenie służy koniecznemu i promującemu życie tworzeniu wspólnoty między człowiekiem a naturą" ${ }^{37}$. Taki cel stawia sobie w ekologicznie ukierunkowanej teologii stworzenia, która zakłada odejście od jednowymiarowych metod badawczych: „Trzeba używać różnorakich sposobów dochodzenia do komunii stworzeń, a ludzie winni mieć tego świadomość. Tych metod szukać będziemy zarówno w tradycji, jak i doświadczeniu, w naukach ścisłych, jak i w wiedzy mądrościowej, w intuicji, ale też w dedukcji”" Ujęcie to można odczytać jako pozytywne odniesienie się do postulatu hermeneutycznej potrzeby relacji teologii - nauki przyrodnicze w teologii stworzenia. W uzasadnieniu takiej potrzeby Moltmann odnosi się do ważnej dla jego teologii stworzenia idei integrowania Boga ze światem, człowieka z przyrodą, a tym samym próby przezwyciężania pewnej dwutorowości obecnej w myśleniu współczesnego chrześcijanina, polegającej na oddzieleniu historii powszechnej od historii zbawienia ${ }^{39}$.

Choć odniesienia do przyrodniczego obrazu świata mają charakter dość ogólny, są jednak przykładem stosowania sformułowanego we wstępie postulatu integrowania różnych wymiarów wiedzy, wyrażającego tym samym integralne myślenie ${ }^{40}$. Jest to jednak bardziej próba integrowania przyrodniczego obrazu świata z teologiczną nauką o stworzeniu. Nieco bardziej szczegółowe odniesienia do terminologii przyrodniczej czy wyraźnie do samej teorii ewolucji odnajdujemy w rozdziale pt. Ewolucja stworzenia. W celu właściwego określenia relacji pomiędzy teologicznym a przyrodniczym spojrzeniem na powstanie świata i człowieka reformowany teolog z Tybingi wychodzi od krytycznej analizy przyczyn dawnego sprzeciwu i uprzedzeń teologii wobec tychże nauk, szczególnie wobec teorii ewolucji. Zasadniczo uprzedzenia te mają swoje źródło w literalnej inter-

\footnotetext{
35 J. Moltmann, Bóg w stworzeniu, 151, 166.

36 Tamże, 187.

37 Tami̇e, 38.

38 Tamże, 39.

39 Por. J. Moltmann, Wissenschaft und Weisheit, 19-21.

40 Tenże, Bóg $w$ stworzeniu, 36.
} 
pretacji tekstów biblijnych o stworzeniu, redukcji tematyki stworzenia jedynie do początku stworzenia (creatio orginalis), czy nieporozumieniach w przyporządkowaniu człowieka w procesie ewolucji ${ }^{41}$. Krytycznie odnosi się on również do mechanicznego przenoszenia na teren teologii używanych dziś do tworzenia obrazu świata w teorii ewolucji takich terminów, jak: samoorganizacja, autoreprodukcja, samouporządkowanie, samoplanowanie, autoregulacja, czy autotranscendencja. Nie do przyjęcia są również dokonywane przez przyrodników, na przykład T.H. Huxleya czy E. Heackela, ewolucjonistyczne interpretacje samej teorii, nierzadko motywowane ideologicznie ${ }^{42}$. Takie interpretacje prowadzą do instrumentalnego wykorzystywania samej teorii do wykluczania możliwości przyjęcia działania Boga w świecie, jak również do mechanicznego przenoszenia jej zasad funkcjonowania na inne dziedziny życia ${ }^{43}$.

Dla uniknięcia dawnych błędów ważne jest zachowanie pewnych zasad metodologicznych, regulujących stosunek między przyrodniczą ewolucją a teologiczną nauką o stworzeniu. Wprawdzie brak jest u Moltmanna dokładniejszych wskazań, jak powinna wyglądać kooperacja między teologią i naukami przyrodniczymi, to jedynak udziela on ogólnych wskazań co do interpretacji chrześcijańskiej wiary w stworzenie w odniesieniu do wiedzy przyrodniczej ukazanej przez teorię ewolucji. Po pierwsze, pojęcie „ewolucja” nie jest synonimem pojęcia „stworzenie”. Ewolucja dotyczy oddzielania i porządkowania tego, co stworzone, natomiast stworzenie opisuje cud zaistnienia w ogóle czegokolwiek. Stąd też nie może zachodzić sprzeczność pomiędzy stworzeniem świata a ewolucją świata, gdyż pojęcia te odnoszą się do różnych aspektów tej samej rzeczywistości. Po drugie, ewolucja, która opisuje ciągłe budowanie materii i systemów życia, zawiera się w tym, co teologia naucza o ciągłym stworzeniu (creatio continua). Teologiczne pojęcie otwartości stworzenia na przyszłość transcenduje właściwe również teorii ewolucji otwarcie na przyszłość. Po trzecie, biblijna nauka o stworzeniu sprzeciwia się statycznemu, zamkniętemu ujmowaniu kosmosu i ma rys eschatologiczny, który odpowiada bardziej obrazowi ciągłego niedopełnienia historii kosmosu ${ }^{44}$. Z takim ujęciem wiąże się konsekwentnie odejście od antropocentrycznego obrazu świata na rzecz teocentrycznego oraz eschatologicznego rozumienia ludzkiego i przyrodniczego świata. Uwzględnienie tych wskazań chroni przed powstawaniem nieuzasadnionych sporów czy konfliktów pomiędzy teologiczną nauką o stworzeniu a teorią ewolucji, jak również stanowi dalsze dookreślenie stosowania

\footnotetext{
${ }^{41}$ Por. A. Anderwald, Teolog pomiędzy kreacjonizmem a ewolucjonizmem, 67.

42 J. Moltmann, Bóg w stworzeniu, 328-329, 333-334.

43 Tamże, 327-329.

${ }^{44}$ Tamże, 336-337.
} 
hermeneutycznej] relacji teologia - nauki przyrodnicze w dochodzeniu do spójnego interpretowania rzeczywistości stworzonej.

Rekapitulując można stwierdzić, że koncepcja teologii stworzenia Moltmanna zawiera odniesienia do przyrodniczego obrazu świata. Jego zdaniem w celu zbudowania adekwatnej ekologicznej teologii stworzenia należy odwołać się do wielu metod badawczych, które dają możliwość ujęcia różnych wymiarów rzeczywistości. Tak określona perspektywa badawcza jest zatem otwarta również na uwzględnienie potrzeby hermeneutycznej relacji teologia - nauki przyrodnicze, która sprzyja integrowaniu świata teologii i nauki. Teolog z Tybingi nie stara się jednak bliżej określić sposobów współprzenikania różnych perspektyw poznania świata. Ogólny charakter ma również sam opis odniesień do nauk przyrodniczych w teologii stworzenia. Nie przekreśla to jednak oryginalności jego ujęcia ekologicznej teologii stworzenia otwartej na potrzebę hermeneutycznej relacji teologia - nauki przyrodnicze. Jest to szczególnie widoczne w późniejszej monografii pt. Wissenschaft und Weihsheit, zwłaszcza zawartych w niej rozważaniach dotyczących stworzenia jako otwartego systemu ${ }^{45}$.

\section{Uwagi końcowe}

W. Pannenberg i J. Moltmann są zgodni, iż współczesna teologia nie może być uprawiana w oderwaniu od nauk przyrodniczych. Obydwaj teolodzy przychylnie odnoszą się do możliwości skorzystania z wiedzy przyrodniczej w opisie niektórych aspektów teologii stworzenia. Każdy z nich czyni to w indywidualny sposób. Ich koncepcje teologii stworzenia można uznać za przykłady zastosowania postulatu hermeneutycznej potrzeby relacji teologia - nauki przyrodnicze. Równocześnie są wymownym przykładem obecnego we współczesnej teologii protestanckiej otwarcia na nauki przyrodnicze i związanego z nim dążenia do integralnego podchodzenia do rzeczywistości. Próbując uporządkować ich argumentację dotyczącą stosowania tego postulatu, można wskazać na dwie racje: negatywną - odnoszącą się do konsekwencji wynikających z odrywania teologii od nauk przyrodniczych, i pozytywną - wskazującą na korzyści dla teologii związane z otwarciem się na nauki przyrodnicze.

Gdy chodzi o pierwszą rację obydwaj wskazują, iż pomijanie w teologii stworzenia wiedzy przyrodniczej powoduje izolowanie rozważań nad dziełem stworzenia od aktualnego obrazu świata. To sprawia, że obraz świata, który chrześcijanin w wierze uznaje za stworzenie Boże, zawiera elementy, które nie są spójne (a czasem nawet sprzeczne) z obrazem świata, na który składają się aktualne

${ }^{45}$ Por. J. Moltmann, Wissenschaft und Weisheit, 45-82. 
wyniki badań nauk przyrodniczych. Sytuacja taka nierzadko powoduje wątpliwość, czy chrześcijańska wiara w Boże stworzenie odnosi się do tego samego świata, który jest przedmiotem badań nauk przyrodniczych ${ }^{46}$. Tam gdzie nie dochodzi w teologii stworzenia ani do uwzględnienia aktualnej wiedzy o przyrodzie, ani wynikającego stąd obrazu świata, mówienie o stworzeniu świata przez Boga staje się „pustą formułą”. Terminem tym posługuje się Pannenberg dla wyrażenia krytyki wobec uprawiania teologii stworzenia, gdy odgórnie rezygnuje z jakichkolwiek odniesień do nauk przyrodniczych. Taka praktyka utrwala sytuowanie stworzenia i przyrody obok siebie, bez jakichkolwiek powiązań, co ostatecznie jest szkodliwe dla samej teologii ${ }^{47}$. Ponadto bez odniesień do wiedzy przyrodniczej niemożliwe staje się krytyczne zweryfikowanie przyjmowanych w danej teologii stworzenia obrazów świata. Bezzasadne staje się również w takiej sytuacji odwoływanie do konieczności prowadzenia badań interdyscyplinarnych w obszarze teologii stworzenia. Podobnie Moltmann uważa za stratę dla teologii separowanie się jej od odniesień do wiedzy przyrodniczej. Prowadzi to do zamknięcia teologii na odkrywanie nowych horyzontów badawczych, inspirowanych zmieniającym się obrazem świata czy przemianami w interpretacji niektórych pojęć przyrodniczych ${ }^{48}$.

Natomiast do pozytywnych racji można zaliczyć dążenia obydwu teologów do przekonywującego usprawiedliwienia teologicznej refleksji nad stworzeniem w kontekście przyrodniczego obrazu świata. Tego typu dążenie daje możliwość uwiarygodnienia prawdy o stworzeniu przez ukazanie możliwości harmonizowania właściwych jej treści teologicznych z przyrodniczymi. Tym samym pokazuje, że poznanie przyrodnicze nie stoi w przeciwieństwie czy konkurencji do treści wiary o stworzeniu. Postulowanie uwzględniania $\mathrm{w}$ teologii stworzenia relacji teologia - nauki przyrodnicze nie ma na celu zacierania różnic między właściwą teologii stworzenia perspektywą spojrzenia na przyrodę, stawiania perspektywy przyrodniczej na równi z teologiczną czy sugerowania jakieś zależności teologii od wyników nauk przyrodniczych. Chodzi jedynie o ukazanie możliwości zintegrowania obydwu perspektyw badawczych w ich mówieniu o tym samym przedmiocie - przyrodzie. To konkretnie oznacza dla obydwu teologów konieczność odnoszenia teologicznych wypowiedzi o stworzeniu do przyrodniczych interpretacji świata. Taka konieczność nie dotyczy samych nauk przyrodniczych, które nie potrzebują uwzględniania teologicznej perspektywy w ramach właści-

${ }^{46}$ Por. W. Pannenberg, Das Wirken Gottes und die Dynamik des Naturgeschehens, w: W. GräB (red.), Urknall oder Schöpfung? Zum Dialog von Naturwissenschaft und Theologie, Gütersloh 1995, 139; TENŻE, Gott und die Natur, 481-500.

${ }^{47}$ Por. W. Pannenberg, Theologie der Schöpfung und Naturwissenschaft, 30; TENŻe, Gott und die Natur, 432.

48 J. Moltmann, Wissenschaft und Weisheit, 21. 
wego im wyjaśniania świata. Natomiast wskazywanie na tego typu konieczność w odniesieniu do teologii stworzenia zakłada stosowania hermeneutycznej relacji teologia - nauki przyrodnicze, która sprzyja tworzeniu integralnej wizji rzeczywistości.

Obaj teolodzy, choć w różny sposób, zdają się zgodnie postulować, iż to teologia dla uwiarygodnienia własnych wypowiedzi musi dążyć do integrowania w ramach własnej refleksji przyrodniczy opis świata. Dla bliższego opisania sposobu harmonijnego dopełniania się tych dwóch różnych perspektyw badawczych Pannenberg używa pojęć współbrzmienia (Konsonanz) i spójności (Kohärenz). Przez posługiwanie się tymi pojęciami, zwłaszcza pojęciem współbrzmienia, pragnie zwrócić uwagę na możliwość łączenia obydwu perspektyw (w znaczeniu integrowania), a nie tylko uznawanie braku pomiędzy nimi sprzeczności. Musi być bowiem możliwe wzajemne powiązanie wypowiedzi zawierających roszczenie prawdy zarówno ze strony teologii, jak i ze strony nauk przyrodniczych ${ }^{49}$. $\mathrm{Z}$ kolei Moltmann w integrowaniu obydwu perspektyw poznawczych widzi nie tylko możliwość przezwyciężenia rozdarcia między człowiekiem (podmiotem) a przyrodą (przedmiotem), które prowadzi do ekologicznej zagłady człowieka i przyrody, ale i zbudowania między człowieczym a nieczłowieczym systemem pewnej symbiozy, która gwarantowałaby przeżycie ${ }^{50}$. Ponadto stały wzrost wiedzy związanej z poznaniem nauk szczegółowych domaga się jeszcze mądrzejszej refleksji nad zgromadzoną wiedzą. Nie do nauki - jak stwierdza Moltmann - ale do mądrości należy przyszłość, jeśli ludzkość pragnie mieć przyszłośćć ${ }^{51}$. W odniesieniu do teologii stworzenia można powiedzieć, że odkrycie jej mądrościowego wymiaru (przesłania), jak pokazuje koncepcja stworzenia Moltmanna, domaga się niejako z konieczności uwzględnienia hermeneutycznej relacji teologia - nauki przyrodnicze.

Podsumowując można stwierdzić, iż zarówno Pannenberg, jak i Moltmann są zgodni, iż teologia stworzenia, zachowując spójność własnych wypowiedzi o rzeczywistości, musi być zdolna nie tylko do zrobienia miejsca innym formom opisu rzeczywistości, ale również do ich zintegrowania. Realizacja tego dążenia, dokonująca się w badaniach interdyscyplinarnych z udziałem teologii, zakłada z konieczności uwzględnienie postulatu hermeneutycznej potrzeby relacji teologia - inne nauki, którego szczególnym przypadkiem jest relacja teologia - nauki przyrodnicze.

\footnotetext{
49 W. Pannenberg, Theologie der Schöpfung und Naturwissenschaft, 32.

${ }^{50}$ Por. J. Moltmann, Wissenschaft und Weisheit, 63.

${ }^{51}$ Tamże, 189.
} 


\section{Bibliografia}

Anderwald A., Teolog pomiędzy kreacjonizmem a ewolucjonizmem. Ekologiczna nauka o stworzeniu Jürgena Moltmanna, „Studia Teologiczno-Historyczne Śląska Opolskiego" 23 (2003), s. 57-71.

Danielewicz Z., Teolog wierny nadziei, w: J. Majewski, J. Makowski (red.), Leksykon wielkich teologów XX/XXI wieku, Warszawa 2003, s. 182-191.

Evers D., Religion and Science in Germany, „Zygon” 50 (2015) nr 2, s. 503-533, http://onlinelibrary.wiley.com/doi/10.1111/zygo.12172/epdf(10.04.2017).

JaskóŁa P., Stwórcze dzieło Boga, Opole 2002.

JASKÓŁA P., Boży duch i ludzka dusza w myśli teologicznej, „Studia Teologiczno-Historyczne Śląska Opolskiego" 29 (2009), s. 291-307.

LebKücher A., Theologie der Natur. Wolfhart Pannenberg Beitrag zum Dialog zwischen Theologie und Naturwissenschaft, Neukirchen-Vluyn 2011.

KüNg H., Der Anfang aller Dinge. Naturwissenschaft und Religion, Tübingen 2005.

Moltmann J., Bóg w stworzeniu, tłum. Z. Danielewicz, Kraków 1995.

Moltmann J., Wissenschaft und Weisheit. Zum Gespräch zwischen Naturwissenschaft und Theologie, Gütersloh 2002.

Moltmann J., Personal recollections of Wolfhart Pannenberg, „Theology Today” 72 (2015) nr 1, s. 11-14.

Neininger R., Welt verstehen - an die Schöpfung glauben, Paderborn - München - Wien - Zürich 2010.

Pannenberg W., Kontingenz und Naturgesetz, w: A.M. Müller, W. Pannenberg (red.), Erwägungen zu einer Theologie der Natur, Gütersloh 1970, s. 33-80.

Pannenberg W., Gott und die Natur. Zur Geschichte der Auseinandersetzung zwischen Theologie und Naturwissenschaft, „Theologie und Philosophie“ 58 (1983), s. 481-500.

Pannenberg W., Schöpfungstheologie und moderne Naturwissenschaft, w: H. Deuser (red.), Gottes Zukunft - Zukunft der Welt, München 1986, s. $137-148$.

Pannenberg W., Systematische Theologie, t. II, Göttingen 1991.

Pannenberg W., Das Wirken Gottes und die Dynamik des Naturgeschehens, w: W. GRÄB (red.), Urknall oder Schöpfung? Zum Dialog von Naturwissenschaft und Theologie, Gütersloh 1995, s. 139-152.

Pannenberg W., Theologie der Schöpfung und Naturwissenschaft, w: J. DorSCHNER (red.), Mensch und Universum, Regensburg 1995, s. 139-152.

Pannenberg W., Geist als Feld - nur eine Metapher?, „Theologie und Philosophie“ 71 (1996), s. 257-260. 
Pannenberg W., God as spirit - and natural science, „Zygon” 36 (2001) nr 4, s. 783-794.

Peters T., In Memoriam: Wolfhart Pannenberg (1928-2014), „Dialog” 53 (2014) nr 4, s. 365-383.

Schwarz H., 400 Jahre Streit um die Wahrheit - Theologie und Naturwissenschaft, Göttingen 2012.

Schwarz H., Wolfhart Pannenberg, w: J.B. Stump, A.G. Padgett (red.), The Blackwell Companion to Science and Christianity, Chichester 2012, s. 611-621, http://onlinelibrary.wiley.com/doi/10.1002/9781118241455.ch53/summary (12.03.2017). 